\title{
THE ADDRESS OF EDWARD CLARK IN EULOGY OF JUDGE SAWYER, LATE OF THE CIRCUIT COURT OF APPEALS.
}

(Delivered before the Circuit Court of Appeals, for the gth Circuit, Jan. 4, 1892.)

\section{May it Please the Court:}

As the great procession of the human race moves down the avenues of time, we find the arrows of death flying thick and fast among us; and we are forced to halt while we provide for our fallen companion the last cold dormitory where the mortal remains shall sleep till the morning of the resurrection.

It would not be unreasonable for a friendly hand to plant a rose-bush among the sods which are placed to cover the earth which hides our friend; and so it seems to me that it cannot be out of place for us to put upon the records of this Court some written expression of our sense of the solemnity of the event.

The Stanford University has lost its President; the San Francisco Law Library has lost one of its founders and most efficient members; the city of San Francisco has lost one of its most valued and respected citizens; the State of California has lost one of its peers, who had no superior in her council-chambers, in the political or judicial departments; the United States has lost a true and noble son and servant and expounder of her laws; this honorable Court, in the first hour of its existence, has lost one of its members; the universal congress of the just and good and wise, whose jurisdiction is not limited by sea or shore, nor is prescribed by any sceptre or confined by any crown, but is broad as our humanity, and co-existent with the march of civilization, has lost as true and noble a heart as ever beat to the majestic impulses of freedom.

We have seen the great sun slowly sink behind the waste of waters; we have seen him rise like a strong man to run a race, dispelling the vapors of the night; and so our thoughts follow the departed as he, rising a resplendent star, and is admitted to the fellowship of the noble army of the good and great which has been harvested from this earth in all preceding generations.

O ye cypresses!-who watch as solemn sentinels over the ever-increasing congress of the great and good and wise, which cluster around the Broderick Monument on Laurel Hill-guard well your treasures! There sleeps the silver tongue and golden lips of Baker, the manly and courageous heart of Broderick, the fertile Latham, and the courtly Sargent, the princely Ralston, the benevolent, unostentatious Selby, the massive brain of Sanderson.

The precious gem of truth contained in the fourteenth amendment of the magne charta of the nimetenth century was not found by chance; it was the result and production of a mighty struggle. The earlier heroes in the fight, Broderick and Baker, went down in bloody shrouds before the glorious gem of truth was cest in English words. As England's Runnymede will ever be remembered as the spot where the great charter was signed by King John, so it remained for this continent to fursish to the human race with that Kohinoor of trath.

In the exposition of this article, and the application of its principles to the affairs of our coast, our deceased jurist has taken a conspicuous part.

The occasion demanded a great mind, and the demand was filled by the deceased. 
In Wo Lee, 26th Fed. Rep., he showed his courage and his wisdom. The Supreme Court of the State stood in direct contradiction to his views. He followed the State Court, and made a masterly presentation of the reasons why said Court was wrong. The United States Supreme Court sustained the reasoning of Judge SAwYER, and overruled the State Supreme Court, in one of the most masterly opinions that ever fell from a Court. II8 U. S. $35^{6}$.

The deceased participated in the solution of the great questions of constitutional law settled in Barbier v. Connolly, and Soon Hing v. Crowley, I13 U.S. 27-702.

As Sirius shines the brightest among all the stars which follow the car of night, so these decisions will blaze down the aisles of time for a thousand generztions. And the student who may not be born for centuries to come, and who goes down to the roots and foundation-stones of law, shall quote Mr. Justice SAwYER in Wo Lee and other cases.

We quote the words of the immortal Garfeld : "Fellow-citizens : God reigns, and the government at Washington still lives." So we repeat the words, adding that Lorenzo Sawyer has closed a long and useful life, and has been summoned to the courts of the celestial city, where, as our turn comes, we all must follow.

Peace to his ashes-glorious be his rest!

Our government is one of laws, and not of men-and it still lives.

Hehas been gathered to his fathers, like a shock of corn fully ripe, having realized his three-score years and ten.

Standing by the mausoleum of the illustrious deceased, the reflection steals upon us, "What shadows we are, and what shadows we pursue!" One hundred and fifteen years ago, Father Serra established his Mission near Sixteenth and Dolores Streets, and a battalion of about eight Mexican soldiers established a military post near yonder presidio. Our deceased jurist was born some fortyfive years later.

He was about twenty-five years old when Commodore Sloat hoisted our starry flag on land and sea.

Young Sawyer realized the grandeur of the event and the glory of the pregnant future. He was among the first of the invading host of civilians intent on founding a new State, where freedom and civilization should hold high converse on the virgin shores of the Pacific. He rallied promptly to our banner, and he gloried in our strength.

From youth to ripe old age he has been bone of our bone and flesh of our flesh. Among the many founders of our heaven-blessed State, for energy, industry, integrity, and mental power, he had no superiors, and few equals. He did not leave us until he had seen a grand harvest gathered from the seed which he had helped to scatter.

Looking westward from his grave, we see the great orb of day creeping slowly down toward that mysterious line where wave and wind hold their perpetual embrace, and beneath we see, sweltering like a mirror in the sunshine, the restless bosom of the grand Pacific, sobbing and sighing like a bride impatient for the coming of her tarrying groom. Upon these ever-changing waters sail the countless barks which prove the skill and courage of our mechanics and navigators, causing them to walk like things of life and joy and beauty over these pathless waters. 